\title{
Service Quality and Customer Satisfaction in the Airline Industry: A Comparison between Legacy Airlines and Low-Cost Airlines
}

\author{
David Mc. A Baker \\ Department of Management, Harmon College of Business and Professional Studies, University of Central Missouri, \\ Warrensburg, MO, USA
}

\begin{abstract}
The purpose of this study was to examine the service quality and customer satisfaction of the top 14 U.S. airlines between 2007 to 2011 using data from the Department of Transportation Air Travel Reports. The objectives of this study were to compare customer satisfaction and service quality with respect to airlines quality dimensions and subsequently to determine the relationships between the dimensions of service quality and passengers' satisfaction on airlines services. A critical review of the literature revealed that the airline industry has been struggling with many challenges: cutting costs, managing fluctuating demand, keeping up with tight quality requirements while trying to maintain superior services and satisfy the needs of various customer groups. Data were collected from the Department of Transportation's Air Travel Consumer Report on the following measures: percentage of on-time arrival, passengers denied boarding, mishandled baggage and customer complaints. Using a quantitative research method, Microsoft Excel version 2010 was used to analyze the data using percentages, mean and standard deviation. Results indicate that while the traditional carriers are converging toward a higher level of service quality, using the four measures, there continue to be significant variation. In this study, over a five year period 2007 to 2011, the service quality of low cost airlines was generally found to be higher than that of traditional legacy airlines. Implications related to operating costs, market share, infrastructure and customer service were evident.
\end{abstract}

Keywords: Quality, service, customer satisfaction, legacy airline, low cost airline

\section{Introduction}

The U.S. passenger airline industry is a major sector within tourism that principally composed of legacy, regional, and low-cost airlines. Legacy airlines support large, complex hub-and-spoke operations with thousands of employees and hundreds of aircraft of various types, with flights to domestic communities of all sizes as well as to international destinations. Generally, regional airlines operate smaller aircraft than legacy airlines such as turboprops or regional jets with up to 100 seats and often operate flights marketed by a legacy airline. Low-cost airlines entered the marketplace after the U.S. airline industry was deregulated in 1978 and typically have a less extensive network and lower operating costs. A low-cost carrier or low-cost airline also popularly known as a no-frills, discount or budget carrier or airline: typically use one type of aircraft with up to 200 seats offering generally low fares in exchange for eliminating many traditional passenger services. To remain competitive, service providers must render quality service to their customers. Customer satisfaction has been at very low levels for decades and according to American
Customer Satisfaction Index, the airline industry scores were the lowest out of 47 other industries during 2012. Past studies have attempted to measure customers' perception of service quality and the effect of customer satisfaction levels on their future behavior, and various strategies for achieving customer satisfaction and customer loyalty have been suggested to companies from the findings of these studies.

Air travel has always been classified as one of the more intangible service industries (Kloppenborg and Gourdin, 1992; Shostack, 1977). This classification has been attributed to the industry exhibiting the five distinguishing characteristics of services as summarized by Clemes, Mollenkopf, and Burn (2000). The air travel industry is part of a steadily growing service sector (Lovelock, Patterson, and Walker, 2004). Ostrowski, O'Brien, and Gordon (1993) suggest that the growth of the service sector not only offers business opportunities but also poses competitive threats for many service marketers, and this is particularly the case for the air travel industry. Traditionally, the airline industry was heavily regulated by governments on where and how airlines could operate (Piercy, 2001) but the Airline Deregulation Act 1978 changed the competitive 
structure of the airline industry (Levin, 1987; Bailey, Graham, and Kaplan, 1985). Now, airline companies were allowed to set prices as well as enter and exit the industry upon meeting insurance and safety requirements. This limited revolution in the freedom for airlines to compete led to many new entries to the industry, and some considerable carnage. Deregulation brought substantial effects on the structure of airlines in USA, Canada and Europe. Low Cost carriers have grown and develop as a result.

Customer satisfaction in airline operations has become critically important and Dennett, Ineson, Stone, and Colgate (2000) suggest that as competition created by deregulation has become more in-tense, service quality in the airline industry has also received more attention. The delivery of a high level of service quality by airline companies became a marketing requisite in the early 1990s, as competitive pressures continued to increase. Most airlines began to offer various incentives, such as the frequent flyer programs, in an effort to build and maintain the loyalty of customers (Miller, 1993). Airline companies also attempted to differentiate their services through the use of computerized reservation systems which were also designed to create customer loyalty in the distribution channels (Lee and Cunningham, 1996). However, despite the airlines' efforts to differentiate their services, an extensive survey of frequent fliers conducted by Ott (1993) revealed that consumers did not perceive any difference from one carrier to another. Ostrowski et al. (1993) noted that when all airline companies have comparable fares and matching frequent flyer programs, the company with better perceived service will draw passengers from other carriers. The purpose of this study is to examine the service quality dimensions of legacy airlines vs. low cost airlines air travel that are perceived to be important by airline passengers. Table 1. show the differences between the two business concepts.

Table 1. Differences between Low Cost Carriers and Legacy Carriers

\begin{tabular}{lll}
\hline Characteristic & Low cost carriers & Legacy carriers \\
\hline Brand & One brand: low price & Extended brand: price/service \\
Price & Simple pricing structure & Complex pricing structure \\
Distribution & Internet, direct booking & Internet, direct, travel agent \\
Checking in & Kiosk, e-tickets & Kiosk, Paper tickets, e-tickets \\
Network & Point-to-point & Hub-and-spoke \\
Classes & One class & Multiple classes \\
During flight & No frills & Frills (free food \& beverages) \\
Aircraft usage (load factor) & Very intensive & Average - intensive \\
Aircraft type & One type & Multiple types \\
Turnaround times & 30 minutes or less & Slow: congestion/complexity \\
Customer service & Generally underperforms & Full service, offers reliability \\
Airport & Secondary & Primary \\
Operational activities & Focus on core - flying & Flying, cargo \\
Target group & Leisure, price and time sensitive travelers & Business and leisure travelers \\
Services & No frequent flyer program or passenger & Frequent flyer program \\
& lounge & passenger lounge \\
\hline
\end{tabular}

Source: Adapted from Holloway (2008) and O'Connell \& Williams (2005).

\section{Literature Review}

\section{Service quality}

Service quality is considered as a critical dimension of competitiveness (Lewis, 1989). Providing excellent service quality and high customer satisfaction is the important issue and challenge facing the contemporary service industry (Hung et al., 2003). Service quality is an important subject in both the public and private sectors, in business and service industries (Zahari et al., 2008). It is the extent to which a service meets or exceeds customer needs and expectations (Lewis and Mitchell, 1990; Dotchin and Oakland, 1994; Asubonteng et al., 1996; Wisniewiski and Donnelly, 1996; Seilier, 2004; Zahari et al., 2008). During the past two decades, service quality has become a major area of attention to practitioners, managers and researchers because of its strong impact on business performance, lower costs, return on investment, customer satisfaction, customer loyalty and gaining higher profit (Leonard and Sasser, 1982; Cronin and Taylor. 1992; Gammie, 1992; Hallowell, 1996; Chang and Chen, 1998; Gummesson, 1998; Lasser et al., 2000; Newman, 2001; Sureshchander et al., 2002; Seth and Deshmukh, 2005). 
The rapid development and competition of service quality, in both developed and developing countries has made it important for companies to measure and evaluate the quality of service encounters (Brown and Bitner, 2007). Several conceptual models have been developed by different researchers for measuring service quality. It is envisaged that conceptual models in service quality enable management to identify quality problems and thus help in planning for the launch of a quality improvement program, thereby improving the efficiency, profitability and overall performance (Seth and Deshmukh, 2005). There are two main aspects that describe and affect both service quality; the actual service customers expected (expected service) and services perceived (perceived service). Fitzsimmons \& Fitzsimmons (2001) explains that the creation of customer satisfaction for a service can be identified through a comparison between service perceptions with service expectation, see Figure 1.

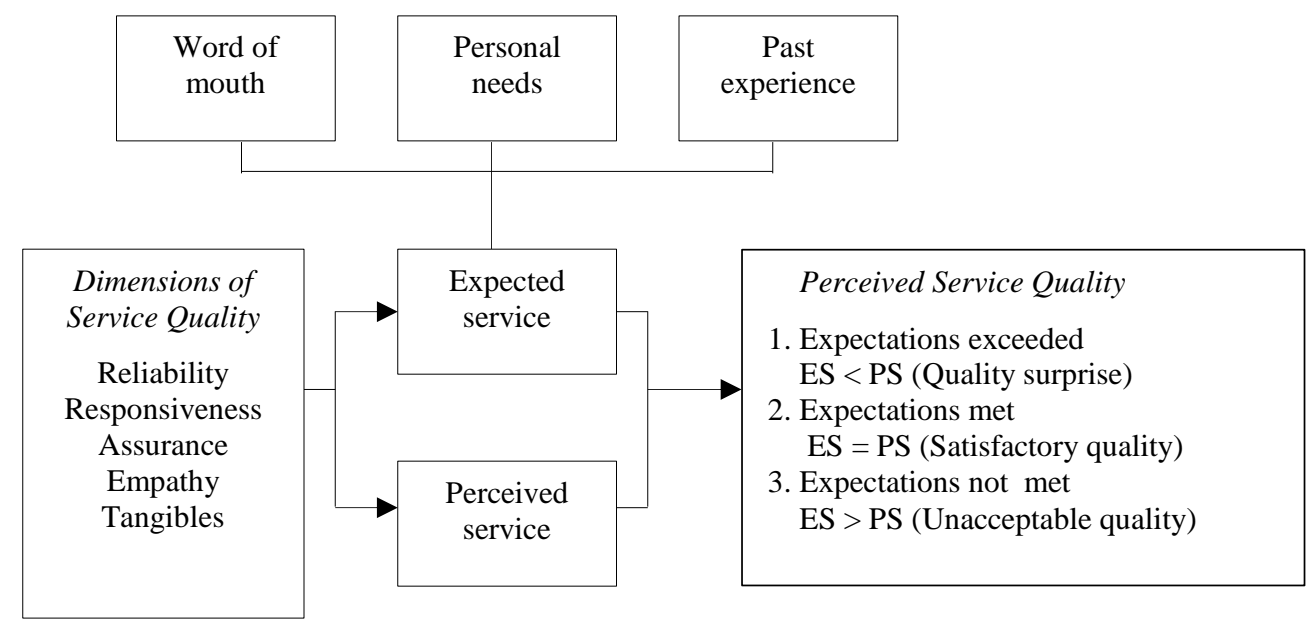

Figure 1. Perceived service quality model, Source : Fitzsimmons \& Fitzsimmons (2001).

Although the definitions of service quality vary, the definitions are all formulated from the customer perspective: that is, what customers perceive are important dimensions of quality (Lewis, 1989). Gronroos (1982) and Parasuraman, Zeithaml and Berry (1988) were the pioneers in the conceptualization of the service quality construct, these authors maintained that the overall perception of quality was a disconfirmation of a customer's expectation and his/her evaluation of a service. The dimensions of service quality have also been debated in the literature. For example, Gronroos (1982) proposed technical (the tangible aspects of service delivery) and functional (the expressive performance of the service) qualities as two critical dimensions of service quality. Alternatively, Parasuraman et al. (1988) proposed five service quality dimensions, namely, tangibles, reliability, responsiveness, assurance and empathy. Rust and Oliver (1994) developed a three-component dimensional model and concluded that the service product (i.e. technical quality), the service delivery (i.e. functional quality), and the service environment were critical dimensions of service quality. Dabholkar, Thorpe, and Rentz
(1994) tested a hierarchical conceptualization of retail service quality that proposed three levels: (1) customers' overall perceptions of service quality; (2) primary dimensions; and (3) sub-dimensions.

Brady and Cronin (2001) adopted the view that service quality perceptions were multidimensional and identified the primary dimensions of their model based on Rust and Oliver's (1994) findings. More recent work by Brady and Cronin (2001) has provided a new and integrated conceptualization of service quality. They argued convincingly that customers form service quality perceptions on the basis of their evaluations of three primary dimensions: outcome quality, interaction quality, and environmental quality; these three primary dimensions are composed of multiple sub-dimensions. The aggregate evaluations of the sub-dimensions form their perceptions of an organization's performance on each of the three primary dimensions, and those perceptions then lead to an overall service quality perception. The debate on service quality dimensions is still ambiguous, but it is generally accepted that perceptions of service quality are multidimensional and the dimensions are industry-specific. 


\section{Customer satisfaction}

Recent interpretations in the consumer domain now couch satisfaction as a fulfillment response. Fulfillment implies that a consumption goal is known, as in basic motives of hunger, thirst, and safety. However, observers of human behavior understand that these and other goals can be and frequently are modified and updated in various ways. Thus, consumer researchers have moved away from the literal meaning of satisfaction and now pursue this concept as the consumer experiences and describes it. In Oliver (1997), satisfaction is the consumer's fulfillment response. It is a judgment that a product or service feature, or the product or service itself, provided (or is providing) a pleasurable level of consumption-related fulfillment, including levels of under or over-fulfillment. Satisfaction is an "overall customer attitude towards a service provider" (Levesque \& McDougall, 1996) or according to Zineldin (2000) an emotional reaction to the difference between what customers anticipate and what they receive. When customers are satisfied, they are more likely to return, while dissatisfied customers are more likely to go elsewhere (Heskett et al., 1994; Strauss et al., 2001; Zairi, 2000).

Since, customer satisfaction is strongly influenced by the interaction between customers and employees (Boshoff \& Tait, 1996), examining employee behavior is critical. Employee behavior, though, is strongly influenced by the operating organizational culture (Chow et al., 2002; Ferris et al., 1998; Pratt \& Beaulieu, 1992; Schein, 1996), “a system of shared values and beliefs that produces norms of behavior and establishes an organizational way of life" (Koberg \& Chusmir, 1987). Where the existing literature relates organizational culture and customer satisfaction, those links are either theoretical or indirect (Gowing \& Lindholm, 2002; Gupta et al., 2005). Quality of service is the focus of the assessment that reflects the customer's perception of the five specific dimensions of service. Conversely, satisfaction is more inclusive, that is, satisfaction is determined by the perception of service quality, product quality, price, situation factors, and personal factors (Zeithaml \& Bitner, 2001), see Figure 2.

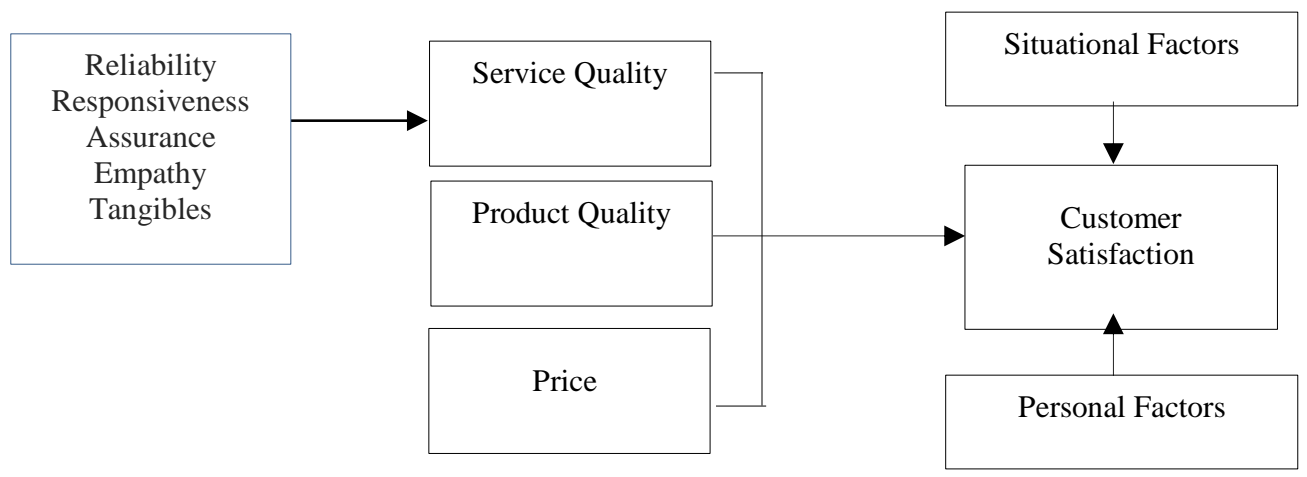

Figure 2. Customer satisfaction model, Source: Zeithaml \& Bitner (2001).

Customer satisfaction has become a key intermediary objective in service operations due to the benefits it brings to organizations (Ranaweera and Prabhu, 2003). The importance of customer satisfaction is derived from the generally accepted philosophy that for a business to be successful and profitable, it must satisfy customers (Shin and Elliott, 2001). Previous research has demonstrated that satisfaction is strongly associated with re-purchase intentions (Cronin and Taylor, 1992; Fornell, 1992). Customer satisfaction also serves as an exit barrier, helping a firm to retain its customers (Fornell, 1992; Halstead and Page, 1992). Several studies have concluded that it costs more to gain a new customer than it does to retain an existing one (Blodgett, Wakefield, and Barners, 1995; Gummesson, 1994). In addition, customer satisfaction also leads to favorable word-of-mouth publicity that provides valuable indirect advertising for an organization (Halstead and Page, 1992; Fornell, 1992). In many industries, having satisfied customers also means that the organization receives fewer complaints (Fornell, Johnson, Anderson, Cha, and Bryant, 1996; Spreng, Harrell, and Mackoy, 1995), hence reducing costs in handling service failures. Researchers also maintain that satisfied customers are willing to pay more for the benefits they receive and are more likely to be tolerant of an increase in price (Fornell et al., 1996; Anderson, Fornell, and Lehmann, 
1994). Shin and Elliott (2001) concluded that, through satisfying customers, organizations could improve profitability by expanding their business and gaining a higher market share as well as repeat and referral business.

\section{The relationship between service quality and satisfaction}

To achieve a high level of customer satisfaction, most researchers suggest that a high level of service quality should be delivered by the service provider as service quality is normally considered an antecedent of customer satisfaction (Cronin, Brady, and Hult, 2000; Anderson et al., 1994; Cronin and Taylor, 1992). However, the exact relationship between satisfaction and service quality has been described as a complex issue, characterized by debate regarding the distinction between the two constructs and the casual direction of their relationship (Brady, Cronin and Brand, 2002). Parasuraman, Zeithaml, and Berry (1994) concluded that the confusion surrounding the distinction between the two constructs was partly attributed to practitioners and the popular press using the terms interchangeable, which make theoretical distinctions difficult. Interpretations of the role of service quality and satisfaction have varied considerably (Brady et al., 2002; Cronin and Taylor, 1992; Parasuraman, Zeithaml, and Berry, 1988), they confined satisfaction to relate to a specific transaction as service quality was defined as an attitude. This meant that perceived service quality was a global judgment, or attitude, relating to the superiority of the service.

Cronin and Taylor (1992) argued against Parasuraman et al.'s (1988) categorization. Cronin and Taylor (1992) found empirical support for the idea that perceived service quality led to satisfaction and argued that service quality was actually an antecedent of consumer satisfaction. Cronin and Taylor (1992) asserted that consumer satisfaction appeared to exert a stronger influence on purchase intention than service quality, and concluded that the strategic emphasis of service organizations should focus on total customer satisfaction programs. The authors reasoned that consumers may not buy the highest quality service because of factors such as convenience, price, or availability and that these constructs may enhance satisfaction while not actually affecting consumers' perceptions of service quality. Cronin and Taylor (1994) later conceded that the directionality of the service quality - satisfaction relationship was still in question and that future research on the subject should incorporate multi-item measures.
The authors suggested restricting the domain of service quality to long-term attitudes and consumer satisfaction to transaction-specific judgments. However, Bitner and Hubbert (1994) determined that service encounter satisfaction was quite distinct from overall satisfaction and perceived quality. Adding to the debate about the distinction between service quality and satisfaction, customer satisfaction has also been operationalzed as a multidimensional construct along the same dimensions that constitute service quality (Sureshchandar, Rajendran, and Anantharaman, 2002). Despite strong correlations between service quality and customer satisfaction, the authors determined that the two constructs exhibited independence and concluded that they were in fact different constructs, at least from the customer's point of view. Brady and Cronin (2001), endeavored to clarify the specification and nature of the service quality and satisfaction constructs and found empirical support for the conceptualization that service quality was an antecedent of the super ordinate satisfaction construct. In addition, the authors found that satisfaction explained a greater portion of the variance in consumers' purchase intentions than service quality.

A reverse casual relationship has also been hypothesized between the two constructs. Rust and Oliver (1994) maintained that while quality was only one of many dimensions on which satisfaction was based, satisfaction was also one potential influence on future quality perceptions. In recent years, organizations are obliged to render more services in addition to their offers. The quality of service has become an aspect of customer satisfaction. It has been proven by some researchers that service quality is related to customer satisfaction. In relating customer satisfaction and service quality, researchers have been more precise about the meaning and measurements of both satisfaction and service quality. Satisfaction and service quality have certain things in common, but satisfaction generally is a broader concept, whereas service quality focuses specifically on dimensions of service. Amidst these debates, it is clear that there is a strong relationship between service quality and customer satisfaction, it can be concluded that service quality had significant impacts on customer satisfaction. Sureshchandear et al. (2002) found that service quality and customer satisfaction were highly related.

\section{Methodology}

This study involves a quantitative secondary analysis of data drawn from the U.S. Department of Transportation (DOT) monthly Air Travel Consumer Reports. The DOT requirement is based on the 
criteria that an airline handled at least $1 \%$ or more of the total domestic scheduled-service passenger revenues for the year. The variables used to evaluate customer satisfaction were; mishandled baggage; ticket over-sales i.e. passengers denied boarding; customer complaints and on-time performance. This study track comparative quality for domestic airline operations for January to December each year for five years 2007 - 2011. Any airline passenger can file complaints with DOT in writing, by telephone, or in person. Complaint categories included flight problems, overbooking-passenger denied boarding, reservations/ticketing/boarding, fares, refunds, baggage, smoking, advertising, credit, tours, and other. Several factors led to a surge of complaints against airlines during 2007 - 2011, lost baggage and airlines full with passengers were stuck on the tarmac for more than seven hours without proper care was given widespread publicity, which in turn led to increased consumer awareness concerning airline quality and the means to file complaints. Statistical mean, standard deviation and percentages are used in the analysis.

\section{Results and Discussion}

It was envisioned that the data collected would reflect the quality of services provided by the various airlines, assessing if whether their performance was on par with the expectations of their customers in terms of overall satisfaction. An analysis of the data can provide guidelines for participating airlines in terms of strategies to improve their services and sustain loyalty among existing customers, as well as help in designing measures to attract new customers. From a consumer perspective, the findings uncover the values that consumers look for in the choice of airline services and other affecting factors.

Table 2. Customer service variables by carriers for the period January to December 2007 to 2011.

\begin{tabular}{|c|c|c|c|c|c|c|c|c|c|}
\hline \multirow{2}{*}{ Airlines } & \multicolumn{2}{|c|}{ \% of Flights On-time } & \multicolumn{2}{|c|}{$\begin{array}{l}\text { Passengers } \\
\text { Boarding }\end{array}$} & Denied & \multicolumn{2}{|c|}{$\begin{array}{l}\text { Passengers } \\
\text { Complaints }\end{array}$} & \multicolumn{2}{|c|}{ Mishandled Baggage } \\
\hline & Mean & SD & Mean & SD & & Mean & SD & Mean & SD \\
\hline $\begin{array}{l}\text { Hawaiian } \\
\text { Airlines }\end{array}$ & 87.44 & 4.88 & 0.08 & 0.06 & & 0.82 & 0.19 & 2.63 & 0.60 \\
\hline Alaska Airlines & 75.98 & 11.31 & 1.08 & 0.57 & & 0.53 & 0.13 & 4.17 & 1.40 \\
\hline Mesa Airlines & 73.20 & 10.49 & 1.84 & 0.54 & & 0.67 & 0.13 & 6.34 & 2.76 \\
\hline US Airways & 77.66 & 6.14 & 1.30 & 0.25 & & 1.99 & 0.71 & 4.31 & 2.49 \\
\hline Airtran Airways & 74.80 & 11.67 & 0.34 & 0.16 & & 0.90 & 0.14 & 2.37 & 1.08 \\
\hline Delta Airlines & 74.34 & 8.73 & 1.18 & 0.89 & & 1.76 & 0.31 & 4.92 & 1.97 \\
\hline $\begin{array}{l}\text { Skywest } \\
\text { Airlines }\end{array}$ & 67.62 & 7.41 & 1.09 & 0.43 & & 0.60 & 0.12 & 6.60 & 2.73 \\
\hline American Eagle & 66.88 & 11.69 & 2.76 & 1.11 & & 1.06 & 0.29 & 9.14 & 2.70 \\
\hline $\begin{array}{l}\text { Southwest } \\
\text { Airlines }\end{array}$ & 73.46 & 8.19 & 1.06 & 0.25 & & 0.26 & 0.04 & 4.19 & 1.04 \\
\hline $\begin{array}{l}\text { American } \\
\text { Airlines }\end{array}$ & 72.92 & 9.47 & 0.76 & 0.14 & & 1.39 & 0.21 & 4.93 & 1.54 \\
\hline Jetblue Airways & 67.50 & 9.73 & 0.01 & 0.01 & & 1.00 & 0.19 & 3.19 & 1.24 \\
\hline $\begin{array}{l}\text { ExpressJet } \\
\text { Airlines }\end{array}$ & 68.76 & 5.17 & 1.88 & 0.06 & & 0.56 & 0.28 & 5.70 & 1.82 \\
\hline Frontier Airlines & 67.10 & 8.14 & 1.40 & 0.63 & & 0.86 & 0.23 & 3.59 & 1.70 \\
\hline United Airlines & 73.36 & 12.26 & 1.09 & 0.24 & & 1.86 & 0.39 & 4.43 & 1.02 \\
\hline
\end{tabular}

To measure customer service, we use annual data on consumer complaints filed with DOT for the period 2007-2011 for the following reasons: In services, every interaction between a consumer and a service provider is a "moment of truth." Consumers compare ex ante expectations about the service to be provided with ex post perceptions concerning the service delivered. Consumer (dis)satisfaction is a function of the difference between expected and perceived service. The more perceived service exceeds expected service, the higher consumer satisfaction will be. Conversely, the more perceived service falls short of expected service, the higher consumer dissatisfaction will be. Service quality is typically defined in terms of consumer (dis)satisfaction. Hence, service quality is inherently subjective in nature. Consumer (dis)satisfaction, in turn, drives repeat purchases (Fitzsimmons \& Fitzsimmons 2001; Metters, King-Metters, \& Pullman 2003; Heskett, 
Sasser, \& Schlesinger 1997; Zeithaml, Parasuraman, $\&$ Berry 1990).

In the five years $2007-2011$, see Table 2. the U.S. airline industry improved in two major categories; on-time performance and baggage handling, with a slight increase in involuntary denied boarding, and customer complaints, according to the data provided by the DOT performance analysis of the top 14 carriers of U.S. airlines that are required to report performance by virtue of having at least $1 \%$ of domestic scheduled-service.

- The results show an improvement over the five years period with airlines on-time arrivals. The rate of on-time arrivals increased to $84.5 \%$ in 2011 from $66.2 \%$ in 2007 with a mean score of $72.9 \%$ overall for all 14 airlines. The top three performing airlines in this category from 2007 to 2011 were Hawaiian Airlines $\quad(\mathrm{M}=87.44, \quad \mathrm{SD}=4.88), \quad \mathrm{US}$ Airways $(\mathrm{M}=77.66, \mathrm{SD}=6.14)$ and Alaska Airlines $(\mathrm{M}=75.98$, $\mathrm{SD}=11.31$ ), see Table 2 .

- The results show an improvement over the five years period with airlines mishandled bags. The rate of mishandled bags decreased to 3.51 per 1,000 in 2011 from 7.4 in 2007 with a mean score of 4.75 per 1,000 overall for all 14 airlines. The top three performing airlines in this category from 2007 to 2011 were, AirTran Airways (M=2.37, SD=1.08), Hawaiian Airways $(\mathrm{M}=2.63, \mathrm{SD}=0.60)$ and JetBlue Airways (M=3.19, $\mathrm{SD}=1.24)$.

- The results show an slight improvement over the five years period with passengers who were denied boarding. Passenger denied boarding decline slightly to 0.95 per 10,000 passengers in 2011 from 0.99 in 2007 with a mean score of 1.13 per 10,000 overall for all 14 airlines. The top three performing airlines in this category from 2007 to 2011 were JetBlue Airways $(\mathrm{M}=0.01, \mathrm{SD}=0.01)$, Hawaiian Airways $(\mathrm{M}=0.08, \mathrm{SD}=0.06)$ and Delta Airways $(\mathrm{M}=1.18$, $\mathrm{SD}=0.89$ )

- The results show an improvement over the five years period with airlines customer complaints. Customer complaints improved to 1.05 per 10,000 passengers 2011 from 1.15 during 2007 with an overall mean score of 1.02 . The top three performing airlines in this category from 2007 to 2011 were Southwest Airlines $(\mathrm{M}=0.26, \quad \mathrm{SD}=0.04)$, Alaska Airlines $(\mathrm{M}=0.53, \mathrm{SD}=0.13)$ and Express Jet $(\mathrm{M}=0.56, \mathrm{SD}=0.28)$.

Passenger complaints about delays, cancellations, and denied boarding, including complaints about being held in airplanes for many hours while awaiting takeoff, have led Congress to consider stronger passenger protections. In recent years, DOT has adopted rules to enhance passenger protections and service quality. First, in 2008, it amended its overbooking rule to increase the required compensation for involuntarily denied boarding, among other things. This has to be considered a factor in the improvement of airlines performance. Second, in late 2009, after a lengthy rulemaking and a task force report on long tarmac delays, DOT issued its first "Enhancing Airline Passenger Protections" rule. The final rule, in effect since April 29, 2010, requires certain U.S. airlines to develop and implement a contingency plan for lengthy tarmac delays, including an assurance that, for domestic flights, the airline will not allow a tarmac delay to exceed 3 hours unless the pilot-in-command determines that there is a safety related or securityrelated impediment to deplaning passengers, or that air traffic control has advised the pilot-in-command that deplaning would significantly disrupt airport operations. The airlines' contingency plans must also include an assurance that adequate food and potable water will be provided no later than 2 hours after the aircraft leaves the gate or touches down, in the case of an arrival, unless the pilot-in-command determines that safety or security considerations preclude such service.

Overall, for this study all four elements got noticeably better from 2007 to 2011 but the biggest improvement were in on-time performance and mishandled baggage. The results indicate that overall for the last couple of years low-cost carriers AirTran Airways, Southwest and JetBlue topped the list of airlines in the four different categories while the legacy carriers trail behind. The regional carrier American Eagle performed worst of the airlines rated in the study. Over the period under study, involuntary denied boarding as a result of overbooking (bumping) for the 14 major airlines in our study combined improved slightly meaning that less people were denied boarding and complaints decreased over the same period thus impacting service quality and customer satisfaction. Both on-time arrival and mishandled baggage had significant reduction during the period under study meaning improvements in these quality service areas. So, service improvements in on-time arrival and mishandled baggage are mirrored by reductions in complaints, the main customer satisfaction indicator in the airline industry. Januszewski (2003) showed with DOT quality data that the more actual performance falls short of expected performance, the more consumers file complaints with DOT. Companies with exemplary customer service understand that delivering a superior experience for consumers drives loyalty and improves top and bottom line results. There is no secret sauce, but there are some commonalities. Customer service standouts tend to have extensive employee training and talent management programs. They also tend to treat workers well by giving them 
incentives, robust career development paths and other benefits. Whereas cost per available seat mile is a good cost measure encompassing all operating expenses, the rate of consumer complaints only measures consumer (dis)satisfaction. The rate of consumer complaints is the only available measure that captures all facets of airline customer service, yet the most common consumer response after a service encounter is to do nothing (Oliver 1997).

There are several implications of this study with regards to airlines operating costs, market share, infrastructure, customer service and satisfaction.

\section{Costs}

At the heart of the low-cost-carrier model is minimizing operating costs. The low-cost carriers profit today because they are competing against highcost legacy carriers. When Southwest Airlines moves into US Air's market, Southwest makes money because its average cost per seat mile is near $\$ 0.08$ while its competitor's is nearer $\$ 0.12$. This difference provides Southwest a profit cushion that allows it to compete on price but still enjoys a profit margin. Several other factors contributed to the low unit costs of the LCCs. The utilization of secondary airports and older terminals reduced airport fees and also, up to a certain point it made it possible to avoid head-on competition with the legacy carriers. Also, less congested airports reduce average flight times and delay incidents. Consequently LCCs started to attract business travelers who value punctuality and frequency. The deployment of homogeneous fleets resulted in savings with maintenance, cockpit training and standby crews. Other important features of the early LCCs include innovative boarding processes that yielded shorter ground waits, no air freight, no hub services, short cleaning times and a lean sales force due to greater reliance on technology - online sales. The lack of unionization among low-cost airlines can be characterized as a myth.

Of the two largest low-cost airlines one is unionized and the other isn't. Although, most of Southwest's workforce is unionized and all of JetBlue's is not, the aggregate cost structure of the two carriers is almost identical; unionization isn't necessarily correlated with high labor costs for lowcost carriers. These carriers also use fewer employees, because they operate point-to-point networks. The main advantage of the low-cost carrier is that it can compete on price with the high-cost traditional carriers. The functional structure of the low-cost carrier is perceptible; moreover, this paper argues that the impact of this unique structure on the airline market is just as evident.

\section{Market share}

Low-cost carriers posted modest global market share gains in 2012, but in the fastest-growing regions for overall air-passenger volumes, the low-cost carriers are not really sharing in the spoils. That's one of the conclusions that can be drawn from an Amadeus Air Travel Traffic Intelligence study of 2012. In air travel's fastest-growing regions, Asia (9\%) and Latin America (6\%), low-cost carriers' market share in 2012 stood at $18.6 \%$ and $24.9 \%$ respectively. In the Middle East, LCCs hold a mere $13.5 \%$ market share. The dearth of a viable LCC presence in Asia, Latin America, and the Middle East contrasts sharply with the situation in Europe, which has the greatest LCC market share in the world at $38 \%$, followed by the South West Pacific (36.6\%), and North America $(30.2 \%)$. Spain $(57 \%)$ has the highest LCC market share in Europe while the UK (52\%) passed the 50\% milestone for the first time in 2012. The status of LCCs varies by country of course but the data show continued increase in LCCs market share. Although Asia has a low LCC market share overall, the Philippines boasts an LCC market share of $61 \%$. The US data provide insights into the impact of the onset of the 2007 economic recession on air travel for business purposes. During national recessions, legacy and low-cost carriers' market niches converge. Although the data tell us nothing about why this has happened, we can speculate that shrinking corporate travel budgets led business passengers to shift from legacy to low-cost carriers in search of value.

\section{Infrastructure}

The expansion of low-cost airlines and secondary airports has significant implications for public and private investors in airports. At the most basic level, the lesson is that the air transport industry is in the midst of a paradigm shift, and that previous assumptions and conventional wisdom should be questioned. The increasingly important role of lowcost airlines is reshaping not only the airline industry, but concepts about the appropriate investments in airport infrastructure. What experience has taught us over the past 30 years may no longer fully apply. Political and business leaders concerned with airport planning and development need to think carefully and cautiously about future investments. Good airport planning, design and management is not what it used to be. Conversely, leaders should anticipate the possibility that low-cost carriers and others will stimulate the demand for distributed airport infrastructure consisting of many smaller airports in contrast to one or more national facilities. Investments in smaller airports that have not yet fully 
established themselves can be risky but many of the investments in large airports have proven themselves to be equally risky and involve far greater amounts of capital. Given the background on airline and airport activity in the US, and the growing role of low cost carriers, the majority of airports outside of major cities are regional airports. There are real opportunities for a number of regional airports to improve their services for the region through the introduction of low cost carriers.

\section{Customer service and satisfaction}

The fourth and perhaps the most obvious attribute of the low-cost carrier is the no frills service that these carriers provide passengers. Instead of providing passengers with a menu of product choices priced within a range, the low-cost carriers offer a single type of product, coach service. This type of service has become very attractive to travelers. Low-cost carriers do not provide meals on flights, which results in a savings of $\$ 5$ to $\$ 10$ per coach passenger. No meals equates to a savings of up to $3.2 \%$ from the average carrier's operating cost. Airline passengers are getting grumpier, less tolerant and complaining more about the shrinking size of passengers seats leg room and being bumped from overbooked flights. Passenger complaints to the U.S. Transportation Department rose by one-fifth last year. The surge came despite a higher percentage of on-time flights in 2011 than during the previous year. The way airlines have taken 130-seat airlines and expanded them to 150 seats to squeeze out more revenue has finally backfired on them. The Internet makes it easier for passengers to air their frustrations. The new online complaints system send passengers complaints directly to DOT, consumers now have a way to complaint more easily. As a result, both low-costcarriers and legacy airlines are putting more efforts in beefing up customer service efforts focusing on quality and customer satisfaction. Unruly, rude, and unhelpful employees can be a problem in any business and airlines are no exception, as evidenced by the complaints about poor cabin assistance and treatment of passengers who were delayed. The most common complaints in the realm of frequent flyer miles made up more than half of the number of miscellaneous problems throughout 2011. These LCCs lack elaborate loyalty programs, which necessitate extra employees, to provide more personalized customer service, and expensive facilities, like airport clubs. Low-cost airlines do not provide costly services, which are only profit enhancing for a hub-and-spoke carrier able to extract high level of rents from customers with a high willingness to pay, business travelers.

\section{Conclusion}

Air travelers who have endured lost bags, delayed flights, long hours on the tarmac without proper food and water, lousy service and getting bumped from full planes might be in for some relief. According to our 2007 - 2011 analysis of data from the DOT, flying is getting better, when measured by the benchmarks used in this study. Industry performance for all four measurements was better in 2011 compared the four previous years. With higher fuel costs, airfares are trending up, although increases vary significantly depending on whether the passenger is flying between major airports or is heading to or from a small or medium-size airport. The ratings are based on data submitted to the Department of Transportation by the 14 airlines that carried the most passengers domestically last year. In judging quality of performance, low-cost carriers that mainly fly between large hubs tend to fare the best, the legacy airlines that have been around since before airline deregulation in the early 1980s tend to fall in the middle. Regional airlines, which often fly smaller planes that have more difficulty avoiding storms, generally pull up the rear.

Nearly half the 14 airlines improved their ontime arrival performance in 2011, and seven had an on-time arrival percentage over 80 percent. The average on-time performance for the industry was 80 percent in 2011, just a tad better than 2010's average of 79.8 percent. Industry performance was better in 2011 , with an average bumping rate of 0.78 per 10,000 passengers compared with 1.08 the year before. AirTran had the best baggage- handling rate, 2.37 mishandled bags per 1,000 passengers. Seven airlines improved mishandled-baggage rates in 2011. The mishandled-baggage rate for the industry decreased from 3.49 per 1,000 passengers in 2010 to 3.35 in 2011. Southwest Airlines once again had the lowest consumer- complaint rate, 0.26 complaints per 100,000 passengers; US Airways had the highest consumer complaint rate at 1.99. Only five of 14 airlines improved their customer-complaint rates for 2011; AirTran, Delta, Frontier, Hawaiian and JetBlue. The majority of complaints fell into four categories: flight problems, 34.9 percent; baggage, 14.3 percent; customer service, 12.1 percent; and reservations, ticketing and boarding, 11.2 percent.

Researchers and practitioners are keenly interested in understanding what drives customer satisfaction, in part because studies find that customer satisfaction is an antecedent of increased market share, profitability, positive word of mouth, and customer retention (Anderson, Fornell, \& Lehman 1994). Consistent with early conceptualizations of the "service concept" as a bundle of goods and services, 
overall satisfaction has been shown to be well explained by satisfaction with constituent service components (Athanassopoulos \& Iliakopoulos 2003; Kumar \& Tsiros 1999; Ross \& Baldasare 1998). The results of this study can provide airline management with information regarding their service quality and the resulting customer satisfaction. As service quality satisfaction occurs when consumers' expectations are met or exceeded, creating more realistic consumers' expectations about the promises that airlines make may increase the level of perceived service quality. Therefore, airlines should offer services that they are capable of delivering. This strategy should enable management to differentiate their brand from the other airlines in terms of service quality. Airlines should also seek to develop strategies that enhance positive behavioral intentions. These strategies should include meeting and exceeding customers' desired service levels, dealing effectively with dissatisfied customers, and confronting customer complaints positively. This study provides a number of contributions and implications for marketing research for both legacy airlines and low fare airlines.

\section{References}

Anderson, E., Fornell, C., \& Lehmann, D.R. (1994). "Customer satisfaction, Market share, and Profitability: Findings from Sweden", Journal of Marketing, 58(1), 53-66.

Asubonteng, P., McCleaty, K.J., \& Swan, J.E. (1996). SERVQUAL revisited: a critical review of service quality. Journal of Service Marketing, 10(6), 62-81.

Athanassopoulos, Antreas D. \& Anastasios Iliakopoulos (2003), "Modeling Customer Satisfaction in Telecommunications: Assessing the Effects of Multiple Transaction Points on the Perceived Overall Performance of the Provider," Production and Operations Management, 12(2), 224-245.

Bailey, E.R., Graham, D.R., \& Kaplan, D. (1985). Deregulating the Airlines, MIT Press Series on Regulation of Economic Activity, Cambridge, MA: MIT Press.

Bitner, M.J., \& Hubbert, A.R. (1994). Encounter satisfaction versus overall satisfaction versus quality. In R.T. Rust and R.L. Oliver (Eds.), Service quality: New directions in theory and practice, Thousand Oaks: Sage Publications, 72-94.

Blodgett, J.G., Wakefield, K.L., \& Barnes, J.H. (1995). "The effects of customer service on consumer complaining behavior", Journal of Services Marketing, 9(4), 31-42.

Boshoff, C., \& Tait, M. (1996). "Quality perceptions in the financial services sector: the potential impact of internal marketing", International Journal of Service Industry Management, 7(5), 5-31.

Brady, M.K., \& Cronin, J.J. (2001). Some new thoughts on conceptualizing perceived service quality. A Hierarchical Approach", Journal of Marketing, 65(1), 34-49.

Brady, M.K., Cronin, J.J., \& Brand, R.R. (2002). "Performanceonly measurement of service quality: a replication and extension", Journal of Business Research, 55(1), 17-31.

Brown, S.W., \& Bitner, M.J. (2007). Mandating a service revolution for marketing. in Lush, R.F. \& Vargo, S.L. (Eds). The Service-Dominant Logic of Marketing: Dialog, Debate and Directions. Armonk, NY: M.E. Sharp, 393-405.

Chang, T.Z., \& Chen, S.J. (1998). Market orientation, service quality and business profitability: a conceptual model and empirical evidence. Journal of Service Marketing, 12(4), 246-264.

Clemes, M., Mollenkoph, D., \& Burn, D. (2000). “An investigation of marketing problems across service typologies", Journal of Services Marketing, 14(7), 573-594.

Chow, C.W., Harrison, G.L., McKinnon, J.L., \& Wu, A. (2002). The organizational culture of public accounting firms: evidence from Taiwanese local and US affiliated firms", Accounting, Organizations and Society, 27(5), 347-60.

Cronin, J., Brady, M.K., \& Hult, G.T. (2000). "Assessing the Effects of Quality, Value, and Customer Satisfaction on Consumer Behavioral Intentions in Service Environments", Journal of Retailing, 76(2), 193-218.

Cronin, J.J., \& Taylor, S.A. (1992). "Measuring service quality: a reexamination and extension", Journal of Marketing, Vol. 56, July, pp. 55-68.

Cronin, J.J., \& Taylor, S.A. (1994). "SERVPERF versus SERVQUAL: reconciling performance-based and perceptions-minus-expectations measurement of service quality", Journal of Marketing, Vol. 58, January, pp. 125-31.

Dabholkar, P.A., \& Thorpe, D.I. (1994). "Does customer satisfaction predict shopper intentions", Journal of Consumer Satisfaction, Dissatisfaction and Complaining Behavior, 7, 161-71.

Dennet, C.E., Ineson, M., Stone, G.J., \& Colgate, M. (2000). "PreBookable Services in the Chartered Airline Industry: Increasing Satisfaction through Differentiation", The Service Industries Journal, April, 20(2), 82-94.

Dotchin, J.A., \& Oakland, J.S. (1994). Total quality management in services. Part 1: understanding and classifying services. International Journal of Quality \& Reliability Management, 11(3), 9-26.

Ferris, G.R., Arthur, M.M., Berkson, H.M., Kaplan, D.M., HarrellCook, G., \& Frink, D.W. (1998). "Towards a social context theory of the human resource management-organizational effectiveness relationship", Human Resource Management Review, 8(3), 235-64.

Fitzsimmons, J. A., \& Fitzsimmons M. J. (2001). Service Management: Operations, strategy, and information technology, 3rd edition, Irwin McGraw-Hill, New York, New York.

Fornell, C. (1992). "A national customer satisfaction barometer: The Swedish Experience", Journal of Marketing, Vol. 56, January, pp. 6-21.

Fornell, C., Johnson, M.D., Anderson, E.W., Char, J., \& Bryant, B.E. (1996). "The American Customer Satisfaction Index: Nature, Purpose and Findings", Journal of Marketing, Vol. 60, October, pp. 7-18.

Gammie, A. (1992). Stop at nothing in the search for quality. Human Resource, 5 (Spring), 35-38.

Gowing, M.K., \& Lindholm, M.L. (2002). "Human resource management in the public sector", Human Resource Management, 41(3), 283-95.

Gronroos, C. (1982). Strategic Management and Marketing in the Service Sector, Helsinki, Finland: Swedish School of Economics and Business Administration.

Gummesson, E. (1994), Relationship Marketing: From 4Ps to 30Rs, Stockholm University, Stockholm.

Gummesson, E. (1998). Productivity, quality and relationship marketing in service operations. International Journal of Contemporary Hospitality Management, 10(1), 4-15.

Gupta, A., McDaniel, J.C., \& Herath, S.K. (2005). "Quality management in service firms: sustaining structures of total quality service", Managing Service Quality, 15(4), 389-402.

Hallowell, R. (1996). The relationships of customer satisfaction, customer loyalty and profitability: an empirical study. International Journal of Service Industry Management, 7(4), $27-42$.

Halstead, D., \& Page, T.J.Jr. (1992). "The effects of satisfaction and complaining behavior on consumers repurchase 
behavior", Journal of Satisfaction, Dissatisfaction and Complaining Behavior, 5, 1-11.

Heskett, J.L., Jones, T.O., Loveman, G.W., Sasser, W.E. Jr., \& Schlesinger, L.A. (1994). "Putting the service profit chain to work", Harvard Business Review, March/April, pp. 105-11.

Heskett, J. L., Sasser, W.E. Jr., \& Schlesinger L.A. (1997). The Service Profit Chain, the Free Press, New York, New York.

Holloway, S. (2008). Straight and level: Practical Airline Economics, 3rd edition, Ashgate publishing limited

Hung, Y.H., Huang, M.L., \& Chen, K.S. (2003). Service quality evaluation by service quality performance matrix. Total quality Management \& Business Excellence, 14(1), 79-89.

Januszewski, S. I. (2003). Essays on the industrial organization of the airline industry, unpublished Ph.D. thesis, Massachusetts Institute of Technology.

Kloppenborg, T.J., \& Gourdin, K.N. (1992). "Up in the Air about Quality", Quality Progress, February, pp. 31-35.

Koberg, C.S., \& Chusmir, L.H. (1987). "Organizational culture relationships with creativity and other job-related variables", Journal of Business Research, 15(5), 397-409.

Kumar P., \& Tsiros M. (1999). "Attribute-Level Performance, Satisfaction, and Behavioral Intentions over Time: A Consumption-System Approach," Journal of Marketing, Vol. 63, January, pp.88-101.

Lasser, W.M., Manolis, C., \& Winsor, R.D. (2000). Service quality perspectives and satisfaction in private banking. Journal of Service Marketing, 14(3), 244-271.

Lee, M., \& Cunningham, L.F. (1996). "Customer Loyalty in the Airline Industry", Transportation Quarterly, 50(2), 57-72

Leonard, F.S., \& Sasser, W.E. (1982). The incline of quality. Harvard Business Review, 60(5), 163-171

Levesque, T., \& McDougall, G.H.G. (1996), "Determinants of customer satisfaction in retail banking", International Journal of Bank Marketing, 14(7), 12-20.

Levin, M.E. (1987). "Airline Competition in Deregulated Markets: Theory, Firm Strategy, and Public Policy", The Yale Journal on Regulation, 4(2), 393-494.

Lewis, B.R. (1989). Quality in Service Sector - A Review. International Journal of Brand Marketing, 7(5), 4-12.

Lewis, B.R., \& Mitchell, V.W. (1990). Defining and measuring the quality of customer service. Marketing Intelligence \& Planning, 8(6), 11-17.

Lovelock, C., Patterson, P., \& Walker, R. (2004). Services marketing: an Asia-pacific and Australian perspective. (3rd ed.). New South Wales: Pearson, Prentice Hall.

Metters, R., King-Metters, K., \& Pullman, M., (2003). Successful Service Operations management, South-Western, Mason, Ohio.

Miller, C. (1993). "Rewards for the Best Customers: Loyalty Programs Increase as Marketers try to Build Relationships", Marketing news (July 5), pp. 1-6.

Newman, K. (2001). Interrogating SERVQUAL: a critical assessment of service quality measurement in a high street retail bank. International Journal of Bank Marketing, 19(3), 126-139.

O'Connell, J.F., \& Williams, G. (2005). Passengers' perceptions of low cost airlines and full service carriers: A case study involving Ryanair, Aer Lingus, Air Asia and Malaysia Airlines, Journal of Air Transport Management, 11(4), 259272

Oliver, R.L. (1997). Satisfaction : A Behavioral Perspective on the Consumer. Singapore McGraw-Hill Companies Inc.

Ostrowski, R.L., O’Brien, T.V., \& Gordon, G.L. (1993). "Service quality and customer loyalty in the commercial airline industry", Journal of Travel Research, 32(2), 16-24.

Ott, J. (1993). Airline Customer Service Rated 'Average' in Survey", Aviation Week and Space Technology, February 1, p. 31
Parasuraman, A., Zeithaml, V.A., \& Berry, L.L. (1988). "SERVQUAL: a multiple-item scale for measuring consumer perceptions of service quality", Journal of Retailing, Vol. 64, Spring, pp. 12-40.

Parasuraman, A., Zeithaml, V.A., \& Berry, L.L. (1994). "Reassessment of expectations as a comparison standard in measuring service quality: implications for further research", Journal of Marketing, Vol. 58, pp. 111-124.

Piercy, N. (2001). Reinventing the Airline Business: If you want dinner, go to a restaurant!, Business Cases Organizations, Case No. 0068.

Pratt, J., \& Beaulieu, P. (1992). "Organizational culture in public accounting: size, technology, rank and functional area", Accounting, Organizations and Society, 17,667-89.

Ranaweera C., \& Prabhu J. (2003). "On the relative importance of customer satisfaction and trust as determinants of customer retention and positive word of mouth", Journal of Targeting, Measurement and Analysis for Marketing, 12(1), 82-98.

Ross Jr. W. T., \& Baldasare, P. M. (1998). "The Asymmetric Impact of Negative and Positive Attribute-Level Performance on Overall Satisfaction and Repurchase Intentions," Journal of Marketing, 62(1), 33-47.

Rust, R.T., \& Oliver, R.L. (1994), "Service Quality: insights and managerial implications from the frontier", in Rust, R.T. and Oliver, R.L. (Eds.), Service Quality New Directions in Theory and Practice, Sage Publications, London, pp. 1-20.

Schein, E. (1996). "Culture: the missing concept in organization studies", Administrative Science Quarterly, 41(2), 229-40.

Seilier, V.L. (2004). Examining Service Quality for homebuyers in the residential real estate brokerage industry. $\mathrm{PhD}$ thesis, Sydney: University of Western Sydney.

Seth, N., \& Deshmukh, S.G. (2005). Service quality models: a review. International Journal of Quality \& Reliability Management, 22(9), 913-949.

Shin, D., \& Elliott, K.M. (2001). "Measuring Customers' Overall Satisfaction: A Multi-Attributes Assessment", Services Marketing Quarterly, 22(1), 3-19.

Shostack, L.G. (1977). "Breaking Free form Product Marketing", Journal of Marketing, 41 (April), 73-80.

Spreng, R.A., Harrell, G.D., \& Mackoy, R.D. (1995). "Service Recovery: Impact on Satisfaction and Intentions", Journal of Services Marketing, 9(1), 15-23.

Strauss, B., Chojnacki, K., Decker, A., \& Hoffman, F. (2001). "Retention effects of a customer club", International Journal of Service Industry Management, 12(1), 7-19.

Sureshchandar, G.S., Rajendran, C., \& Anantharaman, R.N. (2002). "The relationship between service quality and customer satisfaction - a factor specific approach", Journal of Service Marketing, 16(4), 363-379.

Wisniewiski, M., \& Donnelly, M. (1996). Measuring service quality in the public sector: the potential for SERVQUAL. Total quality Management, 7(4), 357-365.

Zahari, W., Yusoff, W., \& Ismail, M. (2008). FM-SERVQUAL: a new approach of service quality measurement framework in local authorities. Journal of Corporate Real Estate, 10(2), $130-144$

Zairi, M. (2000). "Managing customer satisfaction: a best practice perspective", The TQM Magazine, 12(6), 389-94.

Zeithaml, V.A., \& Bitner, M.J. (2001). Services Marketing: Integrating Customer Focus Across the Firms. Boston: TataMcGraw Hill.

Zeithaml, V. A., Parasuraman, A., \& Berry, L.L. (1990). Delivering quality service: Balancing customer perceptions and expectations, New York, NY: The Free Press.

Zineldin, M. (2000). "Total relationship management (TRM) and total quality management (TQM)", Managerial Auditing Journal, 15(1/2), 20-8. 